\title{
Natural history of interaction between Meteorus sp. Haliday, 1835 (Hymenoptera: Braconidae) and its hyperparasitoid Toxeumella albipes Girault, 1913 (Hymenoptera: Pteromalidae)
}

\author{
Sobczak, JF. ${ }^{a *}$, Maia, DP. ${ }^{b}$, Moura, JCMS. ${ }^{c}$, Costa VA. ${ }^{d}$ and Vasconcellos-Neto, J. ${ }^{e}$ \\ aPrograma de Pós-graduação em Ecologia e Recursos Naturais, Universidade Federal de São Carlos - UFSCar, \\ Rod. Washington Luis, Km 235, CEP 13565-905, São Carlos, SP, Brazil \\ bPrograma de Pós-graduação em Parasitologia, Universidade Estadual de Campinas - UNICAMP, \\ Av. Bertrand Russel, CEP 13083-865, Campinas, SP, Brazil \\ 'Programa de Pós-graduação em Biologia Vegetal, Universidade Estadual de Campinas - UNICAMP, \\ Rua Monteiro Lobato, CEP 13083-970, Campinas, SP, Brazil \\ 'Instituto Biológico, Rod. Heitor Penteado, Km 3, CEP 13094-430, Campinas, SP, Brazil \\ eDepartamento de Biologia Animal, Instituto de Biologia, Universidade Estadual de Campinas - UNICAMP, \\ Rua Monteiro Lobato, 255, CEP 13083-862, Campinas, SP, Brazil \\ *e-mail: jobczak@gmail.com
}

Received January 19, 2011 - Accepted March 13, 2011 - Distributed February 29, 2012 (With 1 figure)

\begin{abstract}
Some parasitoids build a cocoon mass that hangs in the host body until the adults emergence, which is an advantage against attack by predators who troll the vegetation in search of prey. However, such behaviour is not effective against the hyperparasitoid attacks. This study reports the interaction between the caterpillar Manduca sexta Linnaeus, 1763 (Lepidoptera, Sphingidae) parasitised by Meteorus sp. (Hymenoptera, Braconidae) larvae and its hyperparasitoid Toxeumella albipes (Hymenoptera, Pteromalidae). This is the first description of the attack and oviposition of T. albipes.
\end{abstract}

Keywords: behaviour, host, cocoon mass, parasitoid.

\section{História natural da interação entre Meteorus sp. Haliday, 1835 (Hymenoptera: Braconidae) e seu hiperparasitoide Toxeumella albipes Girault, 1913 (Hymenoptera: Pteromalidae)}

\begin{abstract}
Resumo
Alguns parasitoides constroem um agregado de casulos que fica pendurado no corpo do hospedeiro até a emergência dos adultos, o que é uma vantagem contra o ataque de predadores que vasculham a vegetação em busca de presas. No entanto, tal comportamento não é eficiente contra o ataque de hiperparasitoides. Este estudo registra a interação entre a lagarta Manduca sexta Linnaeus, 1763 (Lepidoptera, Sphingidae) parasitada por larvas de Meteorus sp. (Hymenoptera, Braconidae), e seu hiperparasitoide Toxeumella albipes (Hymenoptera, Pteromalidae). Esta é a primeira descrição do ataque e da oviposição de T. albipes.
\end{abstract}

Palavras-chave: comportamento, hospedeiro, massa de casulos, parasitoide.

\section{Introduction}

Meteorus Haliday is a large genus with cosmopolitan distribution and comprising more than 250 described species (Muesebeck, 1923; Zitani and Shaw, 2002; Zitani, 2003; Shaw and Nishida, 2005; Stigenberg, 2008). Most of the known species of Meteorus are koinobiont endoparasitoids and generally attack young caterpillars, and some are specialised in parasitising beetle larvae (Shaw and Huddleston, 1991; Shaw, 1995, 1997; Zitani and Shaw, 2002). Meteorus species are commonly recognised by their diverse silk-spinning and cocoon-forming behaviours (Zitani and Shaw, 2002;
Zitani, 2003) and by being gregarious (Huddleston, 1980; Maetõ, 1989, 1990; Shaw and Huddleston, 1991; Shaw, 1995). One parasitoid species is considered gregarious when two or more parasitoid larvae originated from the same mother are developed in a single host being the result of multiple eggs laid in the host, or polyembryonic when a repeated division of a single egg occurs (Gauld and Bolton, 1988). The behaviour of lifting the cocoon mass in this gregarious species of Meteorus could be behaviour against predation, especially by ants. This strategy reduces the 
contact of the cocoon surface or nests with the substrate, this being a defensive behaviour widespread in nature (Zitani and Shaw, 2002). Several species of birds and social wasps (Polistes spp.) lift their nests as some butterflies do the same with their chrysalides, and some species of Ichneumonidae like, Hymenoepimecis japi Sobczak et al., 2009 (Sobczak et al., 2009), and H. argyraphaga Gauld, 2000 (Eberhard, 2000) also lift their cocoons. Although some have considered this behaviour as a defense strategy against predators (Shaw and Huddleston, 1991; Zitani and Shaw, 2002), others considered it less efficient to prevent the attack of pseudoparasitoid or hyperparasitoid (Zitani and Shaw, 2002; Quicke et al., 2006). In this paper we report some biological information on a Sphingidae carterpillar, M. sexta, parasitised by Meteorus sp. and its hyperparasitoid T. albipes.

\section{Material and Methods}

One M. sexta caterpillar feeding on Solanum pseudoquina Sr. Hil. (Solanaceae), was found parasitized by Meteorus sp. with a mass of cocoons hanging from the caterpillar body on the edge of a trail in a protected subtropical humid forest in the Serra do Japi $\left(23^{\circ} 15^{\prime} \mathrm{S}\right.$ and $\left.46^{\circ} 57^{\prime} \mathrm{W}\right)$ in Jundiaí, São Paulo state, Brazil, in February of 2010. The cocoon mass was removed from the body of the host and enclosed in a plastic recipient $(13 \times 11 \times 10 \mathrm{~cm})$ maintained in the laboratory to obtain the adult wasps of Meteorus sp. and its hyperparasitoid. The specimens of Meteorus sp. were deposited in the Departamento de Ecologia e Biologia Evolutiva da Universidade Federal de São Carlos - DCBU-UFSCar collection (PenteadoDias, AM., curator), specimens of hyperparasitoid were deposited in the collection of Insetos Entomófagos Oscar Monte, of the Instituto Biológico de Campinas - IB-CBE (Costa, VA., curator) and the caterpillar was deposited in the collection of Arthropoda Insecta Lepidoptera, Museu de Zoologia da Universidade Estadual de Campinas ZUEC-LEP (Freitas, AVL., curator).

\section{Results and Discussion}

The life cycle of Meteorus sp. begins when the adult female lays eggs on the host body; their larvae emerge and feed on the body of its host, which remains active and responds to stimuli (Zitani and Shaw, 2002).

The oviposition behaviour of Meteorus sp. on M. sexta was not observed. A fifth instar caterpillar of $M$. sexta was found feeding on S. pseudoquina on 20 of February 8:00 PM, showing apparently good health. Some hours later in the same day (10:00 PM) we observed the emergence of Meteorus sp. larvae, each one leaving the host by an individual hole (Figure 1a). The caterpillar M. sexta bit the main vein on the under surface of the leaf and remained motionless. Usually the host dies a few hours after the emergence of parasitoid larvae (Fuester et al., 1993), or remains alive for up to 36 hours (Askari et al., 1977). In this study, we observed that the caterpillar remained alive for up to 72 hours after the emergence of Meteorus sp. larvae. After the emergence from the host body, each larvae built a silk thread measuring around $30 \mathrm{~cm}$ distance from the host and all larvae built together a gregarious cocoon mass, composed of 103 cocoons, hanging from the host body and at $95 \mathrm{~cm}$ from the soil (Figure $1 \mathrm{~b}$ ).

Each silk thread produced by each larvae was joined forming a single cable, which connected the cocoon mass to the host body. The time needed to construct the cocoon mass was 18 hours (4:00 PM of $21^{\text {st }}$ February, 2010) which was measured as soon as the larvae leaves the caterpillar host body. The cocoon mass is $4.5 \mathrm{~cm}$ in length and $2.0 \mathrm{~cm}$ in width, and is predominantly of white colour showing fragile appearance when recently built, but after 4 days, it acquires an orange colour and perhaps becomes more resistant. Shirai and Maetõ (2009) observed that the cocoon built by Meteorus pulchricornis (Wesmael, 1835) hardens gradually considering this an important strategy for avoiding attack by the ant
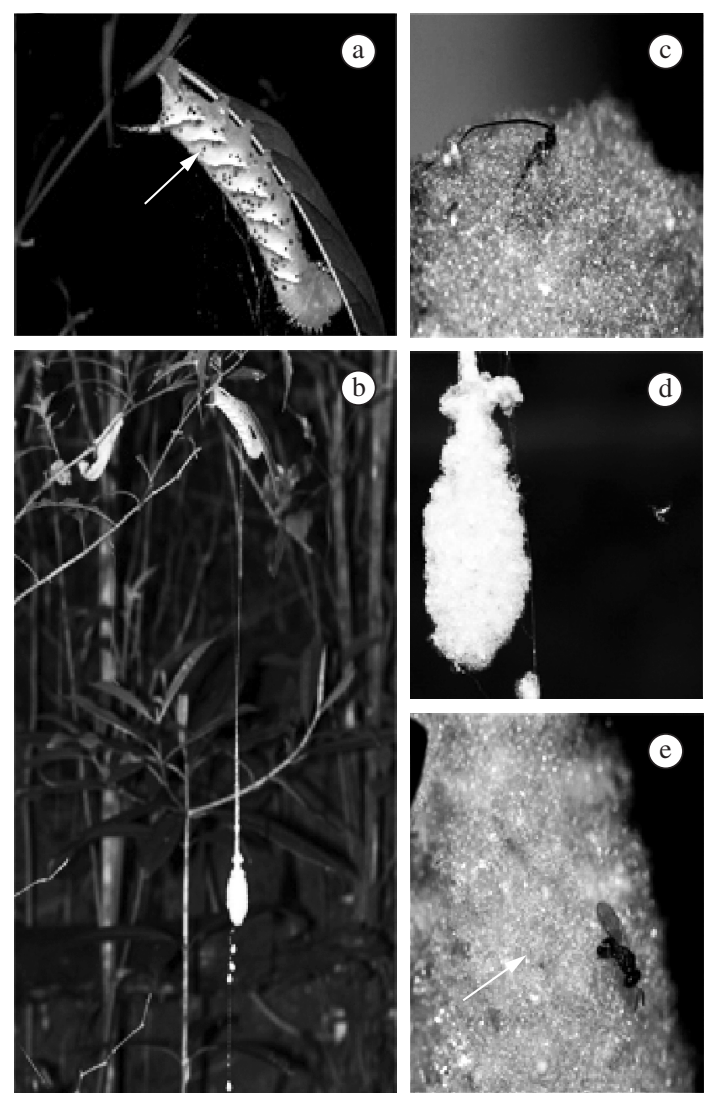

Figure 1. a) Manduca sexta with small holes in its body (setae); b) cocoon mass white and newly built suspended from the host body; c) Meteorus sp. emerged from cocoon mass, observed from the cap of cocoon (setae); d) Toxeumella albipes flies around in cocoon mass; e) Toxeumella albipes oviposition in cocoon mass, seta showing a cocoon. 
Crematogaster matsumurai Forel, 1901. In the laboratory, after 11 days, 44 females and 25 males of Meteorus sp. emerged from the cocoon mass. The wasps emerged simultaneously, cutting symmetrically the tip of each cocoon, emerging from the tangle of wires (Figure 1c).

The gregarious species of the genus Meteorus usually build their cocoons away from the host body, hanging it by a long silk thread reducing the risk of attack by predators that crawl over the vegetation, such as ants (Zitani and Shaw, 2002).

Considering the extensive ability to modulate the behaviour of the host, Meteorus sp. larvae could lead the caterpillar of $M$. sexta to fix in the under position of the leaf allowing abaxial cocoons hanging, avoiding contact with host plant surfaces, thus preventing attacks by predators such as ants but keeping it exposed to hyperparasitoid attacks. Cocoon mass of Meteorus spp. is frequently attacked by hyperparasitoid (Zitani and Shaw, 2002).

We registered the first case in the literature of the attack and oviposition of hyperparasitoid species, T. albipes in the host. The oviposition of T. albipes starts as soon as the wasp finds the cocoon mass of its host Meteorus sp. The wasp flies around the cocoon mass for 20-30 seconds with their antennae directed forward (Figure 1d). After hovering in front of the cocoon mass for four seconds, the wasp flew and landed directly on the cocoon mass. The wasp walked around for 10 seconds on the surface of the cocoon mass, stopped and then inserted its metasoma and ovipositor in the cocoon mass, remaining in this position for 8 seconds (Figure 1e). After oviposition, the wasp continued to move on the cocoon mass searching for other places to lay eggs. A few minutes later, after laying eggs, the wasp flew up and hovered around the cocoon mass, and then returned to the cocoon mass to lay more eggs. The development time of the hyperparasitoid was 13 days. After the development, 32 adults of T. albipes (22 females and 10 males) emerged from Meteorus sp. of cocoon mass during two days. Since the initial number of cocoons in the mass was 103, and that 79 Meteorus sp. emerged from this mass, we concluded that $T$. albipes was responsible for the death of 24 cocoons of Meteorus sp. (about 23\%) which can be considered an important mortality factor in controlling the population of this host. Furthermore, these data indicate that more than one hyperparasitoid can develop from a single cocoon of Meteorus sp.

Acknowledgements - We were financially supported by the Instituto Nacional de Ciência e Tecnologia dos Hymenoptera Parasitoides da Região Sudeste Brasileira (HYMPAR/ Sudeste - CNPq/FAPESP/CAPES), Conselho Nacional de Desenvolvimento Cientifico e tecnológico (CNPq-research grants to J.F. Sobczak, and J.C.M.S.M. Sobczak), Coordenação de Aperfeiçoamento de Pessoal de Nível Superior (Capesresearch grants to D. P. Maia). We thank Dr. Angélica M. Penteado-Dias for the identification of Meteorus sp. We also thank the Prefeitura Municipal de Jundiaí and the staff of the Base de Estudos de Ecologia e Educação Ambiental da Serra do Japi.

\section{References}

ASKARI, A., MERTINS, JW. and COPPEL, HC., 1977. Developmental biology and immature stages of Meteorus pulchricornis in the laboratory. Annals of the Entomological Society of America, vol. 70, p. 655-659.

EBERHARD, WG., 2000. The natural history and behavior of Hymenoepimecis argyraphaga (Hymenoptera: Ichneumonidae) a parasitoid of Plesiometa argyra (Araneae, Tetragnathidae). Journal of Hymenoptera Research, vol. 9, p. 220-240.

FUESTER, RW., TAYLOR, PB., PENT, H. and SWAN, K., 1993. Laboratory biology of a uniparental strain of Meteorus pulchricornis (Hymenoptera: Braconidae), an exotic parasite of the gypsy moth (Lepidoptera: Lymantriidae). Annals of the Entomological Society of America, vol. 86, p. 298-304.

GAULD, ID. and BOLTON, B., 1988. The Hymenoptera. Oxford: Oxford University Press. 332p.

HUDDLESTON, T., 1980. A revision of the western Palaearctic species of the genus Meteorus (Hymenoptera: Braconidae). Bulletin of the British Museum (Natural History) Entomology, vol. 41, p. 1-58.

MAETÕ, K., 1989. Systematic studies on the tribe Meteorini from Japan (Hymenoptera, Braconidae) VI. The pulchricornis group of the genus Meteorus (2). Japanese Journal of Entomology, vol. 57, p. 768-777.

-, 1990. Phylogenetic relationships and host associations of the subfamily Meteorinae Cresson (Hymenoptera: Braconidae). Japanese Journal of Entomology, vol. 58, p. 383-396.

MUESEBECK, CFW., 1923. A revision of the North American species of ichneumon-flies belonging to the genus Meteorus (Hymenoptera: Braconidae). Proceedings of the United States National Museum, vol. 63, p. 1-44.

QUICKE, DLJ., MORI, M., ZALDIVAR-RIVERON, A., LAURENNE, NM. and SHAW, SR., 2006. Suspended mummies in Aleiodes species (Hymenoptera: Braconidae: Rogadinae) with descriptions of six new species from western Uganda based largely on DNA sequence data. Journal of Natural History, vol. 40, p. 2663-2680. http://dx.doi.org/10.1080/00222930601121288

SHAW, MR. and HUDDLESTON, T., 1991. Classification and biology of braconid wasps. Handbooks for the identification of British insects, vol. 7, p. 1-126.

SHAW, SR., 1995. Braconidae. In HANSON, PE. and GAULD, ID. (Eds.). The Hymenoptera of Costa Rica. Oxford: University Press. p. 431-463.

-, 1997. Subfamily Meteorinae. In: WHARTON, RA., MARSH, PM. and SHARKEY, MJ. (Eds.). Manual of the New World genera of the family Braconidae (Hymenoptera). Special Publication of the International Society of Hymenopterists. p. 326-330.

SHAW, SR. and NISHIDA, K., 2005. A new species of gregarious parasitoid (Hymenoptera, Braconidae) reared from caterpillars of Venadicodia caneti (Lepidoptera: Limacodidae) in Costa Rica. Zootaxa, vol. 1028, p. 49-60.

SHIRAI, S. and MAETÕ, K., 2009. Suspending cocoons to evade ant predation in Meteorus pulchricornis, a braconid parasitoid of exposed-living lepidopteran larvae. Entomological Science, vol. 12, p. 107-109. http://dx.doi.org/10.1111/j.1479-8298.2009.00301.x 
SOBCZAK, JF., LOFFREDO, APS., PENTEADO-DIAS, AM. and GONZAGA, MO., 2009. Two new species of Hymenoepimecis (Hymenoptera: Ichneumonidae, Pimplinae) with notes on their spider hosts and behaviour manipulation. Journal of Natural History, vol. 43, no. 43-44, p. 2691-2699. http://dx.doi. org/10.1080/00222930903244010

STIGENBERG, J., 2008. Review of the tribe Meteorini Cresson based on Swedish material (Hymenoptera, Braconidae, Euphorinae).
Stockholms: Examensarbetee Zoologiska Institutionen Stockholms Universitet . Thesis.

ZITANI, NM., 2003. The evolution and adaptive significance of silk use in the Meteorinae (Hymenoptera, Braconidae). Wyoming: University of Wyoming. 126 p. Ph.D. Dissertation.

ZITANI, NM. and SHAW, SR., 2002. From meteors to death stars: variations on a silk thread (Hymenoptera: Braconidae: Meteorinae). American Entomologist, vol. 48, p. 228-235. 